\title{
FEMINISME PADA NOVEL SURGA YANG TAK DIRINDUKAN KARYA ASMA NADIA
}

\author{
Diah Retno Wulandari \\ SMP Negeri 2 Kepohbaru Bojonegoro \\ Email : wulandaridiahretno@gmail.com
}

\begin{abstract}
Abstrak: Tujuan penelitian ini adalah mendiskripsikan (1) Pandangan perempuan tentang gender dalam novel Surga Yang Tak Dirindukan karya Asma Nadia, (2) Ketidakadilan gender yang dialami perempuan dalam novel Surga Yang Tak Dirindukan karya Asma Nadia, (3) Penolakan perempuan dalam novel Surga Yang Tak Dirindukan karya Asma Nadia. Penelitian ini menggunakan pendekatan sosiologis. Landasan teori yang dipakai adalah (1) konsep kajian feminisme, (2) konsep pandangan perempuan, (3) konsep perempuan dan ketidakadilan, (4) konsep penolakan perempuan. Sumber data yang digunakan yakni novel Surga Yang Tak Dirindukan karya Asma Nadia. Teknik yang digunakan untuk mengumpulkan data adalah teknik baca catat. Analis data yang dilakukan yaitu (1) mengindentifikasi satu atau beberapa tokoh wanita di dalam sebuah karya, (2) meneliti tokoh lain, terutama tokoh laki-laki yang berkaitan dengan tokoh perempuan di dalam karya sastra tersebut, (3) mengamati sikap penulis di dalam karya sastra tersebut. Berdasarkan hasil analisis diperoleh (1) pandangan perempuan tentang gender yang terdapat dalam novel Surga Yang Tak Dirindukan karya Asma Nadia, (2) bentuk ketidakadilan gender yang dialami perempuan dalam novel Surga Yang Tak Dirindukan karya Asma Nadia, dan (3) penolakan perempuan dalam novel Surga Yang Tak Dirindukan karya Asma Nadia.
\end{abstract}

Kata kunci: novel, feminisme, gender, ketidakadilan, penolakan.

Abstract: The purpose of this study was to describe (1) the views gender of women in the novel Heaven is Not Missed by Nadia, Asma on several aspects of their live; (2) the gender injustice suffered by women in the Novel Heaven is Not Missed by Nadia, Asma: (3 ) women's resistance in the Novel Heaven is Not Missed by Nadia, Asmaagainst injustice they live. The research uses a sociological approach. Theoretical basis used is (1) the concept of feminism studies, (2) the concept of women 's perspectives, (3) the concept of women and injustice, (4) the concept of women 's resistance in the literature. Source of data used (1) Novel Heaven is Not Missed by Nadia. The technique used in collect the data is reading and note technic. Data analysis was performed based on techniques in conducting studies of feminism, namely (1) identifying one or more female characters in a literature, (2) examine another character, especially male figures relating to the female characters in the literature, (3) observing the am rude of the writer in the literary work. Based on the analysis, obtained: (1) the view gender that there are women in the Novel Heaven is Not missed by Nadia, Asma (2) form of gender injustice experienced by women in the Novel Heaven is not missed by Nadia, Asma, (3) resistance of women in the Novel Heaven is Not Missed by Nadia, Asma.

Keywords: novel, feminism, gender, injustice, resistance. 


\section{PENDAHULUAN}

Perempuan senantiasa menjadi bahasan yang menarik. Dunia perempuan tidak hanya menarik untuk diangkat dalam karya sastra, tetapi juga oleh ilmuilmu lain yang menggunakan wanita sebagai objeknya. Wanita dianggap sebagai makhluk yang lemah lembut dan mempunyai daya tarik tersendiri, tetapi di balik itu semua juga menyimpan segala potensi dan dapat ditunjukkan pada dunia luar tentang eksistensinya.

Deskriminasi perempuan juga tercermin dalam karya sastra. Tokoh perempuan banyak digambarkan mendapat perlakuan secara diskriminatif. Kenyataan tersebut mendorong lahirnya feminisme dalam bidang sastra. Berbekal paparan tersebut, penulis termotivasi untuk mencoba menemukan penggambaran perempuan di dalam karya sastra dalam sudut pandang perempuan. Novel yang berjudul Surga yang Tak Dirindukan karya Asma Nadia diangkat sebagai objek dalam penelitian ini. Asma Nadia memotret poligami dari semua sisi, yaitu sisi suami, sisi korban yang dalam hal ini adalah istri pertama, dan sisi perempuan kedua. Paparan-paparan Asma Nadia dalam tulisannya tersebut mewujudkan berbagai konsep yang jika dipahami dengan baik mampu membuka mata pembaca untuk mengenali perempuan lebih dekat dan kemudian dapat melihat mereka dengan pandangan yang lebih bijak.

Tujuan penelitian ini adalah: (a) Mendeskripsikan pandangan perempuan tentang gender dalam novel Surga yang Tak Dirindukan karya Asma Nadia; (b) Mendeskripsikan bentuk ketidakadilan gender yang dialami perempuan dalam novel Surga yang Tak Dirindukan karya Asma Nadia; (c) Mendeskripsikan perlawanan perempuan dalam novel Surga yang Tak Dirindukan karya Asma
Nadia. Secara teoretis penelitian ini diharapkan dapat memberikan kontribusi terhadap ilmu sastra khususnya sastra feminis. Selain itu, penelitian ini nantinya diharapkan mampu mengembangkan teori feminisme sekarang dengan lebih luas. Secara praktis, penelitian ini memiliki manfaat sebagai berikut: (a) Bagi para peneliti sastra, hasil penelitian ini diharapkan bisa menjadi literatur tambahan untuk penelitian sastra sejenis. (b) Bagi guru bahasa dan sastra Indonesia, hasil penelitian ini diharapkan mampu memberikan pengetahuan tambahan tentang kajian perempuan yang bisa diamalkan kepada siswa. (c) Bagi para mahasiswa, hasil penelitian ini diharapkan dapat menambah wawasan pengetahuan khususnya kajian mengenai perempuan dalam tinjauan feminis.

\section{METODE PENELITIAN}

Pendekatan yang digunakan di dalam penelitian ini adalah pendekatan sosiologis. Sumber data dalam penelitian ini adalah novel Surga yang Tak Dirindukan karya Asma Nadia. Data dalam penelitian ini adalah kutipan katakata, frasa, kalimat, dan paragraf yang terdapat dalam novel Surga yang Tak Dirindukan yang relevan terhadap penelitian. Teknik pengumpulan data yang digunakan dalam penelitian ini adalah teknik baca-catat. Teknik keabsahan data yang digunakan di dalam penelitian ini adalah triangulasi data, triangulasi teori, dan triangulasi peneliti.

\section{HASIL PENELITIAN}

Penelitian yang berkaitan dengan gender dan feminis dalam karya sastra sudah banyak dilakukan. Perbedaan yang utama terletak pada objek penelitian yang diteliti dan kritik feminis yang digambarkan. Penelitian pertama 
dilakukan oleh Yoedo (2001), sebuah tesis dengan judul Karakteristik Feminisme dalam Karya-Karya Nh. Dini yang menemukan kemarahan terhadap laki-laki dalam karya-karyanya. Penelitian kedua dilakukan oleh Sulaiman (2005), sebuah tesis dengan judul Perempuan dalam Sastra Indonesia Mutakhir Karya Wanita Pengarang (Perspektif Gender dan Feminisme). Permasalahan yang dikaji adalah ketidaksetaraan gender yang meliputi marginalisasi, subordinasi stereotype, dan kekerasan terhadap perempuan. Penelitian ketiga dilakukan oleh Maisaroh (2006), sebuah tesis dengan judul "Feminisme dalam Kumpulan Puisi Sebuah Radio, Kumatikan Karya Dorothea Rosa Herliany". Persoalan yang dikaji adalah tingkat kompleksitas permasalahan wanita dan konsistensi semangat atau daya juang feminisme. Penelitian keempat dilakukan oleh Oktasari (2010), sebuah tesis dengan judul Pemikiran Ratna Indraswari Ibrahim tentang Perempuan dalam Roman-Romannya. Persoalan yang dikaji adalah permasalahan perempuan dalam bidang sosial, politik, ekonomi, dan keluarga yang terdapat pada romanroman karya Ratna Indraswari Ibrahim tersebut.

Berdasarkan temuan kajian-kajian yang telah dilakukan oleh peneliti terdahulu sebagaimana tersebut di atas, maka penelitian yang peneliti lakukan ini berbeda dengan penelitian terdahulu. Meskipun teori yang digunakan dalam penelitian ini adalah sama-sama teori feminisme, tetapi fokus penelitiannya berbeda. Karena fokus penelitian berbeda, maka temuannya akan berbeda pula.

Hasil yang diperoleh pada penelitian ini adalah sebagai berikut:

Pandangan perempuan yang terdapat dalam novel Surga yang Tak
Dirindukan karya Asma Nadia terhadap lembaga pernikahan adalah bahwa institusi perkawinan merupakan sesuatu yang sakral. Kesakralan pernikahan merupakan sesuatu yang mutlak. Ketika memilih untuk menikah, maka perempuan berhenti memikirkan dirinya, memikirkan hidupnya. Perempuan telah menandatangani kontrak bahwa ia akan mendedikasikan dirinya secara utuh bagi suami dan anak-anaknya, tanpa menyisakan ruang bagi dirinya sendiri.

Pandangan perempuan terhadap anak-anak hasil pernikahan dalam novel Surga yang Tak Dirindukan karya Asma Nadia adalah bahwa kehadiran seorang anak ternyata sangat penting karena anak adalah anugerah, amanah, dan titipan dari Tuhan yang harus dijaga, dirawat, dan dibesarkan dengan baik. Demi anak-anak, orang tua terpaksa bersikap normal dan berpura-pura seolah semuanya baik-baik saja. Orang tua tidak ingin anak-anak mengetahui bahwa orang tua yang selama ini mereka banggakan telah mengecewakan mereka.

Pandangan perempuan terhadap perselingkuhan dalam novel Surga yang Tak Dirindukan karya Asma Nadia adalah pada dasarnya sikap perempuan dalam novel Surga yang Tak Dirindukan sangat menolak adanya perselingkuhan. Secara normatif, hati nurani manusia akan menolak perselingkuhan. Tidak ada orang yang sengaja ingin menjadi penyebab perselingkuhan, menjadi korban perselingkuhan, atau menjadi pelaku perselingkuhan. Akan tetapi seringkali terdapat latar belakang tertentu yang membuat hal tersebut terjadi.

Pandangan perempuan terhadap dirinya sendiri dalam novel Surga yang Tak Dirindukan karya Asma Nadia adalah sangat dipengaruhi oleh nilai-nilai patriakal, sekalipun sebagian yang lain telah keluar dari hal tersebut. Kemunculan keduanya melalui tokoh- 
tokoh dalam novel Surga yang Tak Dirindukan menjelaskan nilai-nilai yang lahir dari sistem patriakal telah menutup peluang bagi perempuan untuk berkembang, bahkan menutup peluang bagi perempuan untuk mendapatkan kebahagiaan yang ia inginkan.

Bentuk ketidakadilan yang dialami perempuan dalam novel Surga yang Tak Dirindukan karya Asma Nadia berupa beban kerja ganda dan penguasaan ekonomi berkaitan dengan pandangan kaum feminis mengenai 'super woman'. Mereka menyatakan bahwa membuka keran bagi perempuan untuk masuk ke ranah publik, tanpa membiarkan laki-laki untuk masuk ke ranah domestik merupakan merupakan bentuk opresi yang lebih kejam. Para feminis berpendapat bahwa menuntut perempuan untuk credible di luar rumah, dan perfect di dalam rumah merupakan sesuatu yang tidak manusiawi.

Bentuk ketidakadilan yang dialami perempuan dalam novel Surga yang Tak Dirindukan karya Asma Nadia berupa kekerasan fisik adalah dominasi laki-laki terhadap perempuan. Sesuatu yang penting adalah bahwa peristiwa kekerasan tersebut lebih sering terjadi di dalam lembaga terkecil, yaitu keluarga atau juga kekasih.

Bentuk ketidakadilan yang dialami perempuan dalam novel Surga yang Tak Dirindukan karya Asma Nadia berupa penguasaan atas tubuh perempuan, dan seksualitas adalah tubuh perempuan seringkali menjadi sumber malapetaka bagi diri mereka. Dari tubuhnyalah berbagai tindakan pelecehan dan kekerasan seksual yang dialami perempuan berawal mula. Dalam pemikiran yang paling sederhana, sang pemilik tubuh adalah orang yang paling berhak atas tubuh tersebut. Akan tetapi kenyataannya tidak demikian yang terjadi.
Perlawanan perempuan dalam novel Surga yang Tak Dirindukan karya Asma Nadia berupa penolakan terhadap feminitas berangkat dari suatu kondisi masyarakat patriakal yang menggunakan peran gender yang kaku. Hal ini dilakukan untuk memastikan bahwa perempuan harus tetap pasif dengan beberapa penanda feminin seperti penuh kasih sayang, penurut, tanggap terhadap simpati dan persetujuan, ceria, baik, dan ramah. Sebaliknya hak ini juga dilakukan untuk memastikan bahwa laki-laki harus tetap aktif dengan beberapa penanda maskulin seperti kuat, agresif, penuh rasa ingin tahu, ambisius, penuh rencana, bertanggung jawab, orisinil dan kompetitif.

Perlawanan perempuan dalam novel Surga yang Tak Dirindukan karya Asma Nadia berupa memiliki aspek produktif secara ekonomi sebagai sebuah upaya perlawanan terhadap dominasi laki-laki. Hal ini berkaitan dengan apa yang disampaikan oleh seorang pemikir feminis bahwa equalitas dalam relasi perempuan dan laki-laki tidak akan dapat diperoleh oleh seorang perempuan jika ia tidak memiliki peran dalam menyokong kebutuhan finansial keluarganya.

Perlawanan perempuan dalam novel Surga yang Tak Dirindukan karya Asma Nadia berupa penolakan terhadap poligami adalah dengan melawan takdir bahwa perempuan secara kodrati adalah selalu menerima semua hal yang terjadi kepadanya. Hal itu mereka lakukan karena baginya berbagai ketidakadilan yang bermuara pada penderitaan perempuan seringkali dimaknai sebagai ketidakadilan yang diakibatkan oleh ketetapan Tuhan bagi perempuan. Dengan kata lain, para perempuan yang memandang berbagai ketidakadilan tersebut bersifat kodrati, bukan konstruksi masyarakat atas diri mereka.

Perlawanan perempuan dalam novel Surga yang Tak Dirindukan karya 
Asma Nadia berupa perlawanan terhadap kekerasan fisik dan seksual berangkat dari dominasi dan penguasaan laki-laki terhadap perempuan, salah satu konsep yang didengungkan feminis adalah bahwa seorang perempuan harus melakukan perlawanan dengan merebut kembali kepemilikian atas tubuhnya. Kepemilikan atas tubuh menjadi sesuatu yang sering tidak disadari karena telah dimaknai sebagai sesuatu yang bersifat kodrati. Bagi para feminis, hubungan seksual, kehamilan, dan jumlah anak merupakan sesuatu yang menjadi pilihan bagi perempuan, bukan kewajiban atau keharusan.

\section{SIMPULAN}

Berdasarkan hasil penelitian, maka simpulan dalam penelitian ini adalah: Pandangan perempuan yang terdapat dalam novel Surga yang Tak Dirindukan karya Asma Nadia meliputi pandangan terhadap lembaga pernikahan, pandangan terhadap anak-anak hasil pernikahan, pandangan terhadap perselingkuhan, dan pandangan perempuan terhadap dirinya sendiri. Bentuk ketidakadilan yang dialami perempuan dalam novel Surga

\section{DAFTAR RUJUKAN}

Djajanegara, Soenarjati. 2000. Kritik Sastra Feminis: Sebuah Pengantar. Jakarta: PT. Gramedia Pustaka Utama.

Fakih, Mansour. 2001. Sesat Pikir Teori Pembangunan dan Globalisasi. Yogyakarta: Pustaka Pelajar.

Fakih, Mansour. 2002. Analisis Gender dan Tansformasi Sosial. Yogyakarta. Pustaka Pelajar.

Hayati. 2002. Kekerasan Dalam Rumah Tangga. Jakarta: Yayasan Jurnal.

Hellwig, Tineke. 2003. In The Shadow of Change: Citra Perempuan dalam Sastra Indonesia. Jakarta: Woman Research Institute dan Desantara. yang Tak Dirindukan karya Asma Nadia adalah berupa beban kerja ganda dan penguasaan ekonomi, kekerasan fisik, penguasaan atas tubuh perempuan dan seksualitas. Perlawanan perempuan dalam novel Surga yang Tak Dirindukan karya Asma Nadia berupa penolakan terhadap feminitas, memiliki aspek produktif secara ekonomi, penolakan terhadap poligami, dan perlawanan terhadap kekerasan fisik dan seksual.

Adapun implikasi yang diharapkan dari penelitian ini adalah menjadi data sumbangan terhadap teori-teori feminisme. Penerapan kajian feminisme dalam karya sastra menjadi suatu hal yang penting untuk dilakukan tenaga kependidikan di Indonesia. Sebagai agen perubahan, guru dapat memberikan kontribusi bagi sosialisasi peran gender yang diidealkan. Selain itu, yang dapat dilakukan pada waktu mendatang terhadap novel Surga yang Tak Dirindukan karya Asma Nadia adalah berupa kajian psikologi. Hal ini disebabkan karena novel tersebut memiliki data yang kaya sehubungan dengan kondisi psikologi tokoh.

Humm, Maggie. 2000. History of Fiminism in Modern, Feminism : Political, Literary, Cultural. Columbia Encyclopedia: Oxford English Dictionary.

Humm, Maggie. 2002. Modernist Women and Visual Cultures: Virginia Woolf, Photography and modernism. Virginia woolf Society of Great Britain.

Lerner, M.J \& Miller,D.T. (1978). Just World Research and TheAttribution Process, Looking Back and Ahead. California: Psycological Bulletin.

Nurhayati. 2012. Pengantar Ringkas Teori Sastra. Jakarta: Media Perkasa. 
Suharto dan Sugiharto. 2002. Krtik Sastra Feminis, Teori dan Aplikasi. Yogyakarta: Pustaka Pelajar.

Supranto.1996. Sastra Feminis sebuah Pengantar Kritik Sastra, Teori dan
Aplikasinya. Jakarta: Bhratara Karya Aksara.

Thornham, Sue. 2010. Teori Feminis dan Xultural Studies. Yogyakarta: Jalasutra. 